\title{
MARIA CHRITI (Thessaloniki) \\ Oikeiôs as designating 'familiarity' and not 'appropriateness' in Aristotle's creation of words
}

\begin{abstract}
This article deals with the English translations of the adverb oikeiôs in Aristotle's texts. In chapter 7 of the Categories, Aristotle advises speakers to create words if necessary (7a5-7), on the condition that the new word is given oikeiôs. However, the English translations does not render in an accurate way what Aristotle wants to express regarding name-giving, since the adverb oikeiôs, deriving from the adjective oikeios, denotes 'property' and 'familiarity', the second meaning obviously originating from the first. Oikeiôs is crucial for us to comprehend Aristotle's concept of name-giving, since he combines it with forms of the verbs apodidômi ('to define') or legô, more than eight times in this particular chapter, where he is concerned with correct linguistic rendition. In sense of 'familiarity', oikeiôs sheds more light on the philosopher's semantic theory in On Interpretation, helping us to understand exactly how Aristotle conceived of conventionality, i.e., combined with familiarity.
\end{abstract}

Key words: Aristotle, oikeiôs, language, naming, translation

\section{Introduction}

The subject of this paper is the English translation of the adverb oikeiôs in Aristotle's texts, as related to the creation of new terms, in contexts where more light can be shed on the philosopher's approaches to language.

Oikeiôs is a word of Aristotle's current linguistic use, a derivative based on a very popular and productive stem in ancient Greek. However, by examining: $i$ )the way it is contextualized in the philosopher's formulations on language and ii)the way it is applied by Aristotle when he suggests new terms himself, i.e., in the frame of his own lin guistic theory and practices, we can arrive at thought-provoking insights about his approach to 
the very character of linguistic communication, an approach which is not given sufficient attention in contemporary English translations of oikeí $\omega \varsigma$.

For the purposes of this specific study, the methodological steps that are followed are:

- Firstly, the etymological background and the semantic range of oikeiôs, as well asthe respective word family are dealt with, so that the linguistic history of the term is brought to the fore, since we are engaged in an issue of translation.

- Secondly, the way that Aristotle uses the term in the entirety of his corpus is exposed, in order to illustrate the philosopher's general contextualization of oikeiôs. Afterwards, we will specify Aristotle's linguistic theory and practice, so that the way the term is domesticated in Aristotle's philosophy of language and name-giving can be stressed.

- The next step concerns the treatment of Aristotle's linguistic texts that comprise the term oikeiôs on behalf of Ammonius of Hermeias, the Neoplatonic commentator of the $5^{\text {th }}$ cent. AD. Ammonius was the Head of the respective School in Alexandria (see Sorabji 2004, Introduction, with the respective bibliography) ${ }^{1}$ and a brilliant expounder of Aristotle's linguistic views (Chriti 2011a and 2011b), who can illuminate the way that the philosopher's texts could be considered, although such commentaries are not always studied when approaching Aristotle's (and Plato's) philosophy.

It is hoped that in the concluding remarks, the issues that arise when it comes to Aristotelian linguistics from the specific not accurate rendition in English are evident. Furthermore, the terms in which this particular discussion is framed, could afford scholarship an idea of how important it is to take into account all the above or similar parameters when translating the writings of an ancient thinker.

\section{Oikeiôs in Ancient Greek texts and in Aristotle's use}

The adverb oikeiôs derives from the adjective oikeios, which derives from noun oikos (Foikos in dialectal form). This noun designates 'the place where someone lives', the 'house', the 'homeland' and also the 'patrimony'. It has given numerous derivatives, as

\footnotetext{
${ }^{1}$ In general, the School of Alexandria did not have crucial differences with the School of Athens as regards their method and orientation.
} 
it is attested already in Mycenaean texts, as well as many compounds (Chantraine 1970, 777). ${ }^{2}$

The initial semantic content of the word family deriving from oik-has to do with the concepts of 'home', 'origin', 'relation/closeness', as is also certified by ancient Greek dictionaries: the adjective oikeios primarily denotes something/someone belonging to a home or to a household, then a person who is affiliated with a family,i.e., a relative (e.g., Plato, Prot. 316c), then someone friendly, also 'private/one's own' and 'proper, fitting', obviously this last sense of 'compatibility' originating from 'affinity' (LSJ S.v.). It has to be stressed here that, as texts in which it occurs as 'proper' are cited by $L S J$ only Herodotus and Demosthenes, while in the texts of Plato and Aristotle the adjective is interpreted as "belonging to, conformable to the nature of a thing". Aristotle is also referred to in the phrase "oikeĩov óvo $\mu \alpha$ " (Rhetoric, 1404b35), where the adjective has the meaning of 'literal', in opposition to 'metaphorical', a case where 'affinity' and 'closeness' to reality regarding linguistic use is highlighted (see Membrez 2019, concerning the role of oikeion onoma in Aristotle's theory on metaphor and especially pp. 216-217 and 221).

Adverb oikcíws is defined as having the same meanings; in the sense of 'appropriateness' there is not a single philosophical text which is given as an example, while Aristotle's Categories 7a16 is the text given for the sense of 'being on familiar terms', a text which is discussed in detail below. According to Index Aristotelicus by H. Bonitz (1955, 499) Aristotle uses the adjective more than forty times in his treatises with the sense of 'familiar/known' and fewer with the sense of 'literal'. He also uses the adverb twelve times with the meaning of 'in a familiar way' (" $\gamma \omega \omega \rho \mu$ ó $\varepsilon \rho \rho v "$, i.e., "better known" is

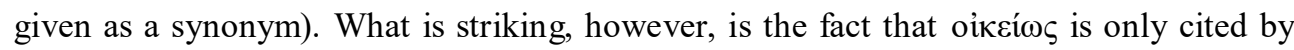
Aristotle in formulations that regard linguistic use: therefore, he selects this specific ad-

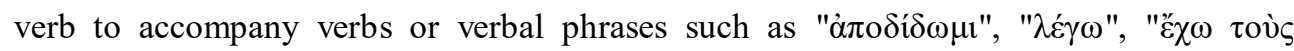

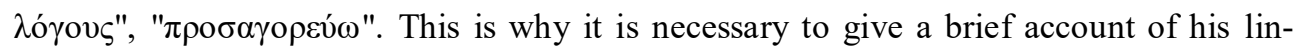
guistic views in general, before delving into Aristotle's linguistic formulations with oikcíws.

\section{Aristotle's linguistic approaches and practices andoikeiôs}

Aristotle's linguistic positions and practices have had a tremendous impact on the history of linguistic ideas (see, e.g., in a selective citation, Benveniste 1966, 63-65;

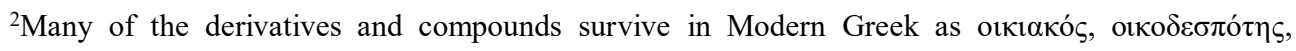

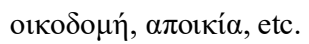


Schofield andNussbaum 1982, 241-266; Weidemann 1991; Manetti 1996, 11-12; Ax 2000, 59-60; Arens 2000; Chriti 2018). ${ }^{3}$ The beginning of On Interpretation, i.e., 16a4-9, the so called semantic text/passage, ${ }^{4}$ reflects the philosopher's linguistic theory in a concise way. According to Aristotle, the articulated human vocal sounds render the conceptual entities that are formed in our minds after the sensory perception. ${ }^{5}$ Aristotle treats two semantic stages, the first one relating vocal sounds with mental states, and the second connecting the latter with experiential data. These three factors in Aristotle's text have received sufficient attention from linguists, psychologists, logicians, and scholars from other disciplines. 'Things' (pragmata; for the semantic content of the term pragmata as 'objects', 'deeds', 'affairs' etc. see On the Soul, 432a3; Meteorology, 379a32; Physics, $226 \mathrm{~b} 30$ and 227b28; Topics, 146a3; Sophistical Refutations, 175a8; Physics, 263a17; Prior Analytics, 70a32; Politics, 1299b18) are perceived by means of the senses. The 'affections of the soul' are the figurative mental states of the soul ${ }^{6}$ which emerge after sensory perception and before linguistic expression, ${ }^{7}$ they are called the likenesses (homoiomata) of things and are also the same for all human beings. Vocal sounds render things and are connected to the affections in a conventional way. In general terms, Aristotle's position is that things are expressed through mental states which are represented in language by meaningful vocal sounds ( $t a$ en têi phônêi) which are not the same for all people. ${ }^{8}$

However, convention is not identified with total arbitrariness for Aristotle, as it can be drawn from what he says a little below in the same treatise. In 16a 26-28 Aristotle

\footnotetext{
${ }^{3}$ Aristotle discusses all aspects of language: $a$ ) physiology of voice in his biological treatises, $b$ ) semantics, c) predication (On Interpretation, Analytics, Topics), $d$ ) the units constituting words and clauses (On Interpretation, Poetics, Rhetoric), e) the potential of linguistic expression for argumentation, persuasion, deceit and pleasure (Poetics, Rhetoric, Sophistical Refutations), f) utterances designating classifications/taxonomies (Categories, Metaphysics).

${ }^{4}$ This specific passage is called as such in the present study.

${ }^{5}$ Now spoken sounds are symbols of affections in the soul, and written marks symbols of spoken sounds. And just as written marks are not the same for all men, neither are spoken sounds. But what these are signs of the primordial affections of the soul are the same for all; and what these affections are likenesses of - actual things - are also the same (adapted trans. J. L. Ackrill).

${ }^{6}$ Due to the fact that I do not find the identification of these affections with 'thoughts' convincing for reasons that are explained in Chriti 2018, I prefer to refer to them as mental products/states/entities.

7 They are either the first meanings formed by the figurative impressions of things, or concepts as results of thinking in general (or both).

${ }^{8}$ The fourth term, 'those that are written', ta graphomena, renders the graphic representations of spoken sounds.
} 
states that a use of a word becomes symbolic as soon as it is agreed upon by the members of a linguistic community. Therefore, his belief in convention is not identical with Hermogenes' extreme conventionalism in Plato's Cratylus (for an overall discussion of the comparison between the Cratylus and Aristotle see Chriti 2018 with the respective bibliography),as Aristotle declares that the symbolic use of a word needs to have the consent of the members of a linguistic community:

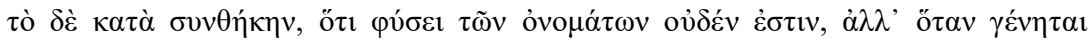

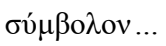

"by convention" was introduced because nothing is by nature a noun or name - it is only so when it becomes a symbol... (trans. by E. M. Edghill).

Consequently, he does not claim that any person can impose any name, but that an utterance has to be accepted as symbolic by the speakers. This means that convention has the sense of 'agreement' for Aristotle for the sake of human communication. The limits to convention are defined by the role of a symbol as a token, for the representation of which the speakers agree on accepting one and the same codification, a codification in which

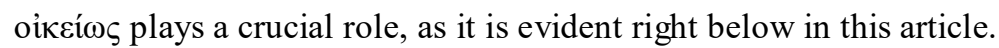

The significance of mutual consent as regards linguistic use can be cross-checked by the Categories, a treatise that has not received sufficient attention when it comes to the philosopher's approaches to language. In the CategoriesAristotle advises speakers to create names under certain conditions. The advice itself is totally compatible with believing in the conventional character of language: hadn't Aristotle claimed that language is a product of human convention, he wouldn't have encouraged speakers to create words. But how should mankind apply new utterances? In the Categories Aristotle describes the way that human beings should apply names to things and, more specifically, in chapter 7, which is cited by $L S J$ for the term oikeiôs and where Aristotle treats reciprocation (" $\pi \rho{ }^{\prime} \varsigma$ $\tau \iota ")$, he embarks on the issue of its linguistic representation, by admitting that sometimes a linguistic expression is not possible by using the current vocabulary and, at the same time, by advising speakers to create words if necessary (Categories, 7a5-7; see also $\mathrm{Ni}$ comahean Ethics,1108a17-19; Aristotle's advice is also discussed by Kotzia 2007a, 1092):

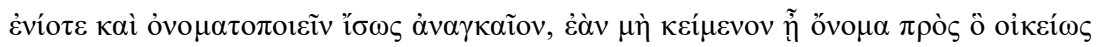
$\grave{\alpha} v \dot{\alpha} \pi \mathrm{o} \delta 0 \theta \varepsilon i ́ \eta$

It may sometimes be necessary even to invent names, if no name exists in relation to

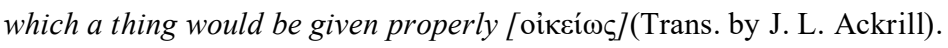


It should be primarily pointed out that we are dealing with the first occurrence of

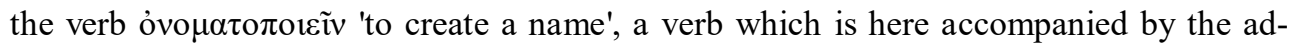
verb oikeios. Aristotle suggests that we should invent names for unnamed subjects, on the condition that the new term is given oikeiôs. Let us try to investigate how the philosopher conceives of the relation between linguistic rendition and oikeios, given: $i$ ) the range of the word's semantic content itself and more specifically in Aristotle as presented above and ii) the principle lines of his linguistic formulations, since it is in a linguistic context that oikeios occurs. Unfortunately these two factors have not been taken seriously into account in the English translations of the adverb as "properly". In the edition of the Loeb Classical Library, H. P. Cooke (1967) translates as "in correlation / correlative terms" (used also by Ackrill a little below, in his translation of7a5-7), which does not seem very accurate either, but is better understood in comparison to "properly", since it is combined with "exactness", rendering the character of the suggested correlation more clear: "exactness" refers to linguistic affinity, which is close to the sense of 'familiarity' that Aristotle wants to emphasize with oikeiôs. (In their excellent edition with a French translation of the Categories, F. Ildefonse and J. Lallot also preferred to use the term "approprié": "...Parfois, il est peut-être nécessaire de forger un mot, si il n'existe pas de mot disponible qui fournisse une réponse appropriée à la question du relatif... "; 2002, 87).

Let us return to the Greek text: the importance of oikeiôs is evident by the fact that

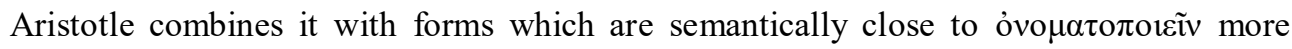
than eight times in this particular chapter, where he is concerned with correct linguistic rendition (see right below; see also Nicomachean Ethics, 1119b33; Physics, 195b3). First of all, it can be said that according to Aristotle's advice, the concept of 'appropriateness' is the wished result and not a presupposition when it comes to establishing a new term: in the text of the Categories, the advice including oikeiôs is given as a condition, as a guideline, as something prior to any kind of 'appropriateness'. This condition can't be anything else than the 'affinity' of the newly suggested utterance with the speakers' current linguistic use, a relation that can render the new convention familiar and not strange, a proximity that results in an appropriate new utterance. Thus, right after his advice, Aristotle states that there is no reciprocation if it is not given oikeiôs in language by saying that "a rudder is rudder of (or somehow else related to) a ruddered" and that "a head would be given oikeioteron (and this is the exact text given by the $L S J$ for the meaning 'being on familiar terms') as of a headed than as of an animal, because it is not as being an animal that a thing has a head..." (Categories, 7a8-17).

And Aristotle concludes (Categories, 7a18-20): 


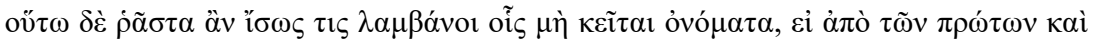

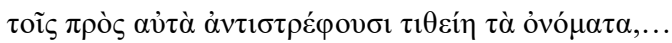

This is perhaps the easiest way to lay hold of things for which there are no established names - if names derived from the original relatives are assigned to their reciprocating correlatives... (trans. J. L. Ackrill).

Reciprocation is not valid if not expressed as it should be, and members of a linguistic community should always invent familiar names, i.e., names that designate an actual relation in terms of reciprocation. Aristotle explains how a conventional 'agreement' can be done oikeiôs, when he encourages speakers to use "derivation from the original relatives", as it is formulated in this text. Eventually, established linguistic material should be used in name-giving, a material that the speakers are familiar with. Judging from his treatment of reciprocation in the examples of the rudder and the head, this familiar linguistic deposit that designates known concepts can be used to express the new meanings that are related to the named ones. In other words, an affinity between things can be designated by an affinity between utterances, which means that familiarity between words is necessary when rendering related things.

Especially helpful concerning the importance of linguistic familiarity that corresponds to a conceptual proximity in name-giving is a text which is completely irrelevant to logic or linguistics. In the Meteorology Aristotle again uses the term oikeiôs to approve of a specific linguistic use in his mother tongue (Meteorology, 347a10-12):

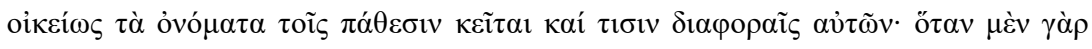

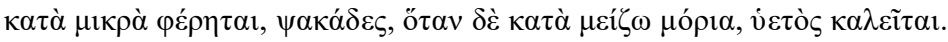

The text is translated as follows in the Loeb series:

And there are appropriate names for these processes and for some of their subspecies - for instance when water falls in small drops it is called drizzle, when in large drops, rain(Transl. by H. D. P. Lee)

Again oikeiôs is not translated as familiar but as appropriate, a synonym of proper. However, in the text from the Meteorology, the only way of treating Aristotle's attribution of oikeiôs to the use of the terms psakades and huetos is their close linguistic relation with current linguistic material, i.e., their verbal proximity with other linguistic utterances in use: the form psekas means 'drop of rain' and is etymologically related to the verb psakazô ('to rain in small drops'), while the form huetos means 'rain' and derives from the verb huô ('to rain'). Eventually, these nouns have been attributed oikeiôs to the particular physical phenomena, because they are linguistically related to the verbs that designate the processes resulting in these phenomena. Meanwhile, in the French transla- 
tion of Belles Lettres by P. Louis, this specific text from the Meteorology is rendered as: "Des noms particuliers ont été donnés à ces phenomènes..." (1982):here it is apparent that the new names cannot be random, but again familiarity is not highlighted.

It should be pointed out that Aristotle does not seem to care about the grammatical forms of the words that he approves of, but he emphasizes the attribution of names as related to established utterances. Consequently, oikeiôs in language means for Aristotle using a word which is verbally close to established utterances with which speakers designate contents relative to the one that needs to be named.

\section{Aristotle's Familiar Suggested Terms}

The way that Aristotle conceives of the importance of 'familiarity' in linguistic use is evident even in his own suggestion of new terms, one of his indisputable contributions to the history of philosophy. (Generally speaking, ancient Greek philosophical vocabulary is an innovation as a whole, since it emerged gradually and alongside with ancient Greek philosophical reflection; see the bibliography given by Kotzia 2007a. Ancient commentators had stressed the attribution of names on behalf of the philosophers: see, e.g., Porphyry in his commentary on Aristotle's Categories, 55.12-24 and Dexippus in his commentary on the same treatise, 6.10-23).

Aristotle's linguistic choices have raised discussions ever since antiquity. He suggests terms for what he treats very often and scholarship owes him the systematization of terminology in several disciplinary fields, such as biology, ethics, physics etc. (see, e.g., Swiggers and Wouters 2002, 9-10, regarding linguistic concepts and terms). He states that his current vocabulary is insufficient for what he wishes to investigate by using a word with a notion of his own for this very purpose: anônumos ('without name'; more than seventy times in his texts, the specific term is used by Aristotle to denote the lack of terms in linguistic treatment: see, e.g., On the Soul, 418a1, 419a4, 419a32; Nichomachean Ethics, 1107b2, 1108a17; On the History of Animals, 490b19, 515b10; Poetics, $1447 \mathrm{~b} 9$, etc. In some cases he declares that "there is no established name": onoma gar ou keitai; Categories 7a13). Contemporary scholars like D. Bostock (1994, XI),J. Barnes $(1981,42)$ and A. Bäck $(2000,130)$ have spoken of Aristotle's unusual language, while eminent scholars have studied significant aspects of the philosopher's semantic practices (see, e.g., Bäck 2000), as well as the interconnection between Aristotle's semantics and ontology in the context of his argumentative strategies (see De Rijk 2002; Bäck 2000 and 2014). 
However, to what extent can scholarship talk about "unusual/strange" new terms in Aristotle's linguistic practices, given that he is never distanced from already used utterances? Aristotle always stays faithful to the importance of conceptual and verbal proximities for the production of new terms and their acceptance by the receivers: as is obvious in the examples below, conceptual relevance between the new meaning and the already named one leads him to a proposal of a familiar term in his linguistic suggestions, on the basis of his current linguistic material (for a detailed survey of this very practice see Chriti 2018).Thus, e.g., in the case of schêma which is a commonly used word, the new concept that emerges from Aristotle's research and does not have a name in current linguistic usage is the 'figure of a syllogism'. Aristotle resorts to a relative concept, which is 'form, figure' and already has a name in his mother tongue, schêma. So, here-attributes the word to the new unnamed meaning: thus, the word schema is usedfor the first time by Aristotle with the meaning 'figure of a syllogism'.

Aristotle's linguistic suggestion departs from the concept in question; he uses a relative concept that already has a name, and, it is on the basis of this specific name that he suggests a new term. As long as the current word is related to a new sense,i.e., a sense that has not yet been named and established in use, the reattributed word can be considered as a new term. Even in the case of his famous entelecheia, Aristotle doesn't do anything different, since he exploits the existent words en, telos, echô, along with their semantic contents in his current linguistic practice, so as to coin entelecheia absolutely oikeiôs: the new concept that he wants to name is: 'inner power guiding to a goal', the relevant concepts, the names of which he has at his disposal are 'in', 'goal', 'to have', designated by the respective vocabulary.

Under no circumstances does Aristotle use an utterance which has nothing to do with his contemporary vocabulary, a vocabulary that designates concepts related to what he wants to name: whether he suggests a common Greek word, or he creates a derivative, or coins a neologism etc., it is by resorting to the deposit of his mother tongue's vocabulary that he proposes terms. The named concepts are those that supply the philosopher with the linguistic material, so as to pick a familiar word or to coin a new - but always familiar - one: for Aristotle, name-assigning ends up with an evident verbal proximity between a used utterance and the newly suggested one, i.e., the result is always familiar. Therefore, no term is attributed as a solution in an arbitrary way, because Aristotle is obviously concerned with verbal proximities for the sake of familiarity in linguistic communication. The philosopher is interested in rendering his linguistic suggestions accessible and acceptable by the members of his linguistic community, so that they can agree on adopting the specific conventions and integrating them in their usage. 


\section{Aristotle's oikeiôs interpreted as 'familiarly' by Ammonius of Hermeias}

Aristotle's Neoplatonic commentator Ammonius son of Hermeias discusses the way that the philosopher uses oikeios in his commentary on On Interpretation. Ammonius treats Aristotle's linguistic behavior in the light of the two Neoplatonic commentatory principles, i.e., the "principle of agreement" (see Karamanolis 2006) ${ }^{9}$ between Plato and Aristotle (the particular tendency goes back to Aristotle's immediate circle: see Kotzia 2007b, 194-201)and the principle "explaining Aristotle from Aristotle". ${ }^{10}$ Ammonius is a distinctive case of a Neoplatonic commentator with interests in language (see Chriti 2011a and2011b) and the only one - to our knowledge — who attempts to reconcile Plato and Aristotle (as Sorabji stresses, Porphyry and Ammonius were mostly focused on the agreement between Plato and Aristotle in general: 2004, 14) in the field of linguistic views (see also Kotzia and Chriti 2014). The commentator claims that Aristotle fundamentally agrees with Plato in terms of language, Plato's views being expressed by Socrates in the Cratylus, ${ }^{11}$ Socrates mediates the two extreme positions of his interlocutors, i.e., the absolute "naturalism" held by Cratylus and the absolute "conventionalism", supported by Hermogenes: Ammonius believes that Aristotle is in harmony with what Plato expresses through Socrates, ${ }^{12}$ i.e., a wise reconciliation of the two contrasted opinions held in the dialogue.

To prove that Aristotle does not oppose to Socrates, Ammonius does not have to delve into Aristotle's refutation of Cratylus' view, as the philosopher explicitly declares the conventional character of language. What Ammonius needs to do, is to certify that Aristotle does not adopt the attitude of Hermogenes either, so that it can be highlighted that Aristotle expresses Socrates' moderated stance. The commentator resorts to Aristotle's texts to retrieve his examples, following the respective principle (see above): he declares that Aristotle expresses his opposition to Hermogenes' extremity in many cases

\footnotetext{
${ }^{9}$ The specific principle was followed by the commentators in different degrees and the only ones who did not apply it were Themistius and, much later, Michael Psellos from the circle of Anna Comnene. ${ }^{10} \mathrm{Cf}$. Aristarchus' doctrine "explaining Homer from Homer".

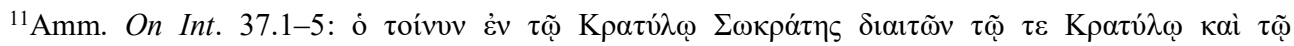

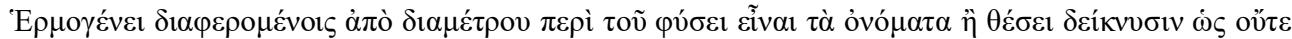

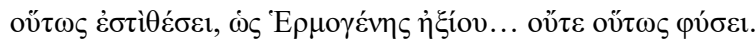

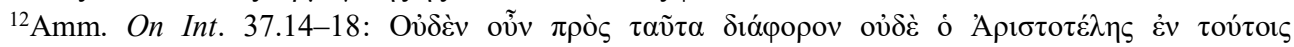

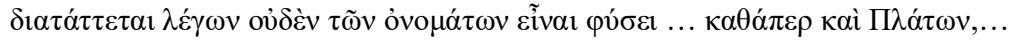


in his treatises, when the philosopher endeavors to indicate that names are "compatible with things"(Amm.,On Int. 37.18-19):

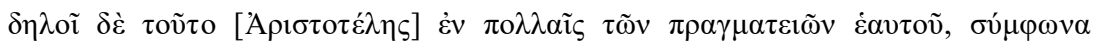

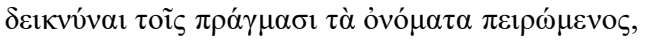

$\mathrm{He}$ [Aristotle] makes that clear in many of his treatises, where he attempts to show that names are consonant with things (Transl. D. Blank)

What does Ammonius mean by stating that Aristotle expresses his agreement with Socrates (and Plato) by using words that are "consonant with things"? (The adjective that he uses is $\sigma 0 ́ \mu \varphi \omega v \alpha$, which is translated as "consonant" by D. Blank in his edition of Ammonius' text). Which are the Aristotelian words that express Socrates' compromising policy? Before embarking on specific examples that Ammonius cites from Aristotle's writings, we can get an idea about the character of such utterances from the commentator's perspective, by cross-referring to his following statement in the same commentary (Amm., On Int.36.23-25):

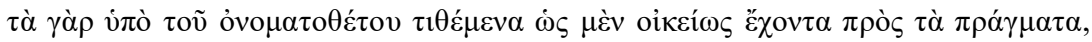

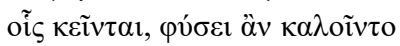

This passage is translated by D. Blank as follows:

For what is imposed by the name-giver as being appropriate (oiksí $\omega \varsigma$ ) to the things for which they stand would be called on the one hand by-nature.

Oikeiôs in Ammonius' text is translated in English as "being appropriate", maybe following the standardized English translations of Aristotle's text. Nevertheless, what is important here is that the content of oikeiôs in name-imposing is acknowledged by Ammonius as "by-nature", i.e., in contrast to what Hermogenes sustains. The commentator explicates how he considers this specific adverb in his commentary on the Categories, relat-

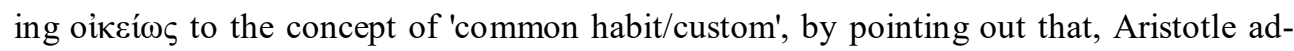

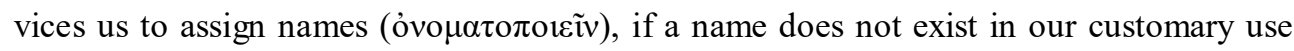

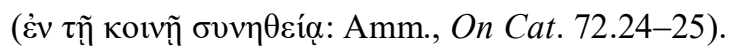

Consequently, as it can be concluded from Ammonius' writings in his commentaries on the Categories and on On Interpretation: a) oikcíos denotes a practice which is subsequent to common linguistic habits and $b$ ) for this very reason the results of such practices can be considered "by-nature", obviously revealing that Aristotle does not adopt Hermogenes' extreme conventionalism. Ammonius recognizes as "familiar", "consonant with things" and not "arbitrary" some of Aristotle's "words" cited right above, including 
the case of $\dot{\varepsilon} \nu \tau \varepsilon \lambda \dot{\varepsilon} \chi \varepsilon 1 \alpha$, as well as the terms from the Meteorology, something which reveals how well Ammon ius has studied (Amm., On Int. 37.20-24).

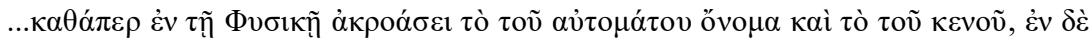

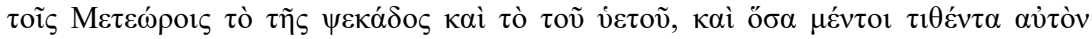

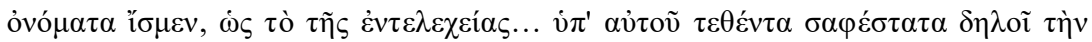

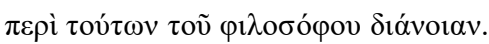

For example, in the Physics lecture, the name of 'spontaneity' and that of 'void', or in the Meteorology that of 'raindrop' and 'shower', as well as the names that we know that he posited, such as 'entelechy'... These names posited by him show very clearly what the Philosopher thought about these matters (transl. D. Blank)

The commentator states for the above cases of Aristotle's terms that they show clearly what the philosopher thought about the character of language and Ammonius' explanations of Aristotle's linguistic theory and practice can be completed by the commentator's treatment of Porphyry's Introduction, where he is also occupied with the necessity of suggesting "familiar names" (Amm., On Porph. 'Intr.' 50.19-51.6):

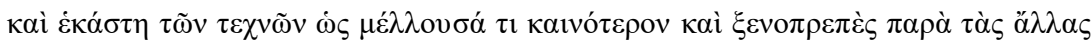

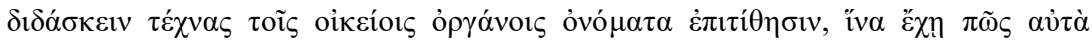

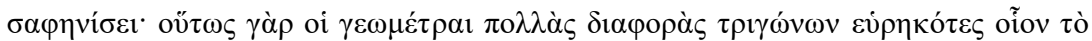

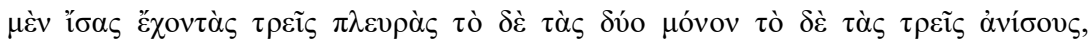

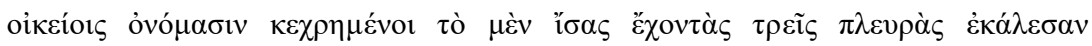

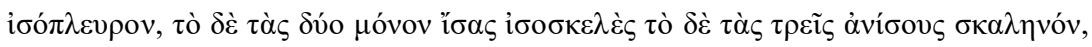

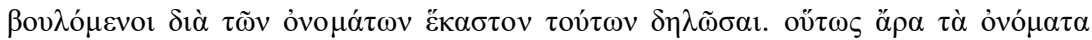

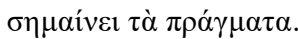

This text should be translated more or less as follows, where adjective oikeĩosseems to mean 'proper', in the sense of 'one's own / familiar':

And each art that aspires to teach something newer and not standard beside other

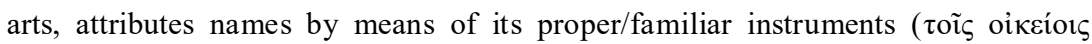
ópróvors), so as to accomplish it with clarity; thus, the geometers, who have found many different types of triangles, such as the one that has three equal sides, the other two and another with three unequal ones, have used familiar names (oikcíors óvó $\mu \alpha \sigma v v$ ) and called the first equilateral, the second isosceles and the third scalenus, aiming at designating each with the respective name.

Ammonius here underlines the need of "each art" to impose new names for unknown subjects, appellation swhich could seem strange to the listeners/learners. The specific necessity has to be dealt with by scholarships' own "tools", i.e., by the disposable means of each field, so that the new terms can be familiar to those who perceive them; distinc- 
tive is the case of geometers, Ammonius continues, who have named the diverse types of triangles according to their characteristics of sides.

It can be argued that the specific text expresses the co-existence of: $a$ ) the Platonic/Socratic concept of 'art' (in the Cratylus, Socrates defines the techne which is followed by the name-giver: Crat. 389a2; 393d4; 389d4-390a8; 390e1-4; 387c1 and 6-7; $388 \mathrm{c} 1$ ), with the Socratic 'tool', an attribution to words when Socrates claims that a name functions as a "didactic tool" (ő $\gamma \alpha v o v \delta 1 \delta \alpha \sigma \kappa \alpha \lambda \iota \kappa o ́ v)$ and as an imitation ( $\mu$ í $\mu \eta \mu)$ which is "by-nature", meaning that it fits the nature of what is named; ${ }^{13} b$ ) the latter Socratic

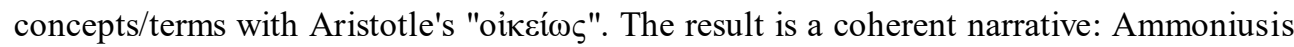
faithful to his view that the Aristotelian approach to language is not opposed to the Platonic one as expounded by Socrates and this is why he combines linguistic concepts and terms which could be considered as separated. The outcome is that he applies for the first time such an interpretation of what it means to attribute new names by rendering verbal affinities as "tools" at the service of the art of naming exercised by geometers and other savants; ${ }^{14}$ Ammonius explicitly says that familiarity is presupposed for clarity and every science should use its "familiar tools" in order to assign understandable names to new findings that have to be communicated.

The invention of "new names", based upon already used utterances by Aristotle certifies for Ammonius that names are neither arbitrary nor random in Aristotle's own linguistic suggestions and thus the Neoplatonic commentator can reach the wished conclusion: the philosopher does not adopt Hermogenes' "total arbitrariness" as long as he is never distanced from familiar utterances, something that reveals his intention to suggest names that are consonant with things he needs to name. This kind of compatibility is interpreted by Ammonius as the rejection of the "by-nature" character of language on behalf of Aristotle and total arbitrariness is now proved to be ruled out by "Ammonian" Aristotle, who is in harmony with Plato because of this very reason.

\section{Concluding remarks}

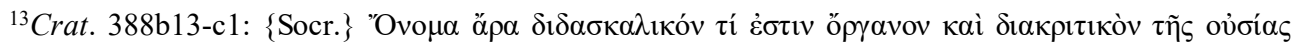

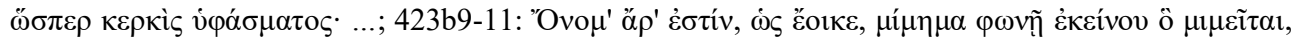

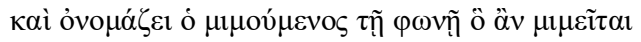

${ }^{14}$ See also Ammonius' remark on the necessity of following a language's structure and rules during word derivation, so that new words do not sound strange to native speakers: On Cat. $72.16 \mathrm{ff}$ and $73.8 \mathrm{ff}$.
} 
Let us recapitulate, by saying, first of all, that the meaning of 'appropriateness' does not occur, neither for the adjective oikeios, nor for the adverb oikeiôs in philosophical texts when it comes to linguistic use. Two occurrences in Aristotle's texts given by $L S J$ have both adverb and adjective cited as designating 'proximity'. Of course it would not be unreasonable to argue that the concept of 'properness' could be considered as originating from 'familiarity' in the case of oikeios, since 'appropriate' is probably something or someone known and close to us, with which/whom we are familiar with. In English and French too, proper and proper respectively mean both 'private' and 'convenient/right', maybe because it feels proper/right to be with someone/something we know and are familiar with.

This is also the case with Aristotle's advice to create new terms, and also with his suggestions and approval of certain linguistic usages: they are all appropriate, but they can be considered as such due to their origins from "home", which is the familiar environment of ancient Greek linguistic use. That is why the adverb oikcí $\omega \varsigma$ as interpreted and translated in Aristotle's texts needs careful reconsideration when it comes to the philosopher's linguistics, because its contextualization in his respective theory and practice remains decisive throughout his corpus. Aristotle's use of oikcí $\omega$ çin the entirety of his corpus always refers to the sense of 'familiarity' and there is no evidence to substantiate that he does something different in his linguistic texts, a view which can be reinforced by his linguistic practices, let alone the fact that he resorts to oikeios only when he refers to linguistic acts. Therefore, this specific adverb occurs side-by-side with verbs which designate naming very frequently in Aristotle's texts and this point seems to have gone virtually unnoticed regarding the English translations of oikcí $\omega \varsigma$.

Aristotle's use of oikeiôs is totally integrated in his philosophy of language, as it is expressed in both first two logical treatises. The philosopher is an adherent of the conventional character of language, but he centers on the concept of 'agreement' between the members of a linguistic community; symbolic uses of words and familiarity have complementary roles in human communication, according to Aristotle's theoretical formulations. He sustains that words are products of agreement in mankind and human beings are absolutely authorized to suggest new names when they feel that they lack in utterances, but their proposed terms should be smoothly integrated in their current linguistic use.

The presupposition for this effective enrichment of vocabulary is familiarity: as long as newly coined utterances are introduced in a familiar way, i.e., not distanced from already used words, linguistic communication cannot be prohibited and appropriateness is the result, a point missed by the standardized Engl ish translations of the respective texts. As it is evident in On interpretation, the Categories and also the way that Aristotle ap- 
proves of a linguistic rendition in the Meteorology, he concerns himself with the issue of exploiting the linguistic deposit of his mother tongue and this is something that merits emphasis, since his concern is advanced in his writings as expressed by oikcí $\omega s$. Besides, being based on his mother tongue's material is what exactly Aristotle does in every single one of his hundreds linguistic suggestions in his treatises. Henceforth, translating oikcí $\omega \varsigma$ as 'properly / in an appropriate way' may not seem misleading on first acquaintance, but on closer inspection it can be considered as divergent, regarding the significance of familiarity in Aristotle's positions and practices.

Verbal familiarity as exploited in total harmony with human habit is an issue deeply looked into by Ammonius of Hermeias in Aristotelian onomastics and, not only does the commentator approve of name-attribution supported by the disposable vocabulary, but he also theorizes it by contextualizing it into the discussion on the character of language.

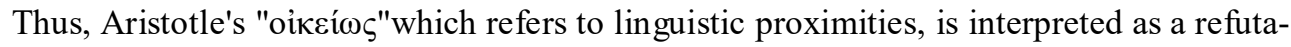
tion of Hermogenes' extreme conventionalism and these affinities are explicitly rendered by Ammonius as "tools" of disciplinary fields in name-assigning.

Ammonius is right: Aristotle does not support the absolute arbitrariness of Hermogenes in Plato's Cratylus, as it is revealed by his linguistic suggestions which could be familiar to and accessible by ancient Greek speakers, regardless of their degree of origi-

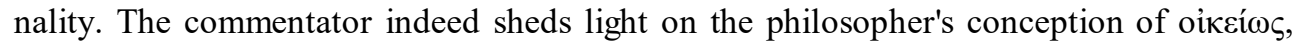
independently of his attempt to reconcile Aristotle with Socrates/Plato, as he ought to, according to the tradition of his School in Alexandria: through the lenses of Ammonius, Aristotle is a thinker with specific tools in his hands, just like every technites and he has to apply these tools in his techne of philosophical research. His armory consists of the already established names that can be of assistance when he searches for ways to call what emerges in his inquiries.

Anyone could hardly disagree with the approach that language is the oikeĩov tool of philosophy. Ammonius has definitely a good point, since philosophy has been developed along with philosophical vocabulary by ancient Greek thinkers, who created terms originating from their everyday familiar language and were thus used oikcícs.

Dr. Maria Chriti, Aristotle University of Thessaloniki, School of Modern Greek, mchriti[at]gmail.com 


\section{References}

Ackrill, John Lloyd. Aristotle, Categories and De Interpretatione, translated with Notesand Glossary. Oxford: Clarendon Press, 1968.

Arens, Hans. "Sprache und Denken bei Aristoteles". In Silvain Auroux et al (eds.). History of the Language Sciences/Geschichte der Sprachwissenschaften/Histoire des sciences du langage. Vol. I. Berlin and New York: De Gruyter, 2000, 367-374.

Ax, Wolfgam."Aristoteles (384-322)". In Wolfgam Ax and Farouk Grewing (eds.) Lexis und Logos. Studien zur antiken Grammatik und Rhetorik. Stuttgard: Franz Steiner Verlag, 2000, 48-72.

Bäck, Allan. Aristotle's Theory of Predication. Leiden, Boston, Köln: Brill, 2000.

Barnes, Jonathan. Aristotle's Posterior Analytics. Clarendon Aristotle Series, ed. by John Lloyd Ackrill. Oxford: Clarendon Press, 1975.

Baxter, Timothy M. S. The Cratylus: Plato's Critique of naming. Philosophia antiqua 58. Leiden / Boston: Brill, 1992.

Benveniste, Emile. "Catégories de pensée et catégories de langue". In Problèmes de linguistique génerale 1, 63-74. Paris: Gallimard, 1966.

Blank, David. Ammonius on Aristotle's "On Interpretation" 1-8, Cornell: Duckworth, 1996.

Blank, David. "The Organization of Grammar in Ancient Greece". In Silvain Auroux et al (eds.). History of the Language Sciences / Geschichte der Sprachwissenschaften / Histoire des sciences du langage. Vol. I. Berlin and New York: De Gruyter, 2000, 400-417.

Christidis, Anastasios-Foivos, Maria Arapopoulou and Maria Chriti (eds). A History of Ancient Greek: From the Beginnings to Late Antiquity. Cambridge: Cambridge University Press, 2007.

Chriti, Maria. "Neoplatonic Commentators on Aristotle: The 'Arbitrariness' of the Linguistic Sign". In Ancient Scholarship and Grammar. Archetypes, Concepts and Contexts, eds. Stephanos Matthaios, Franco Montanari, Antonios Rengakos.Trends in Classics 8. Berlin and New York: De Gruyter, 2011a, 499-514.

Chriti, Maria. "Ammonius' Commentary on Aristotle's De Interpretatione: Language is both by Nature and by Convention", Beiträge zur Geschichte der Sprachwissenschaft 21.1 (2011b), 1-24.

Chriti, Maria. Aristotle as a name-giver: The Cognitive Aspect of his Theory and Practice. CHS Research Bulletin: A publication of the Center for Hellenic Studies, 23.05.2018 http://www.chs-fellows.org/2018/05/23/report-aristotle-as-name-giver/ 
Cooke, Harold P. and Hugh Tredennick. Aristotle. The Categories, On Interpretation, Prior Analytics. The Loeb Classical Library. London: Heinemann. Cambridge, Massachusetts: Harvard University Press, 1967.

De Rijk, Lambert Marie. Aristotle. Semantics and Ontology. Vol. I: General Introduction. The Works of Logic. Leiden, Boston, Köln: Brill, 2002.

Frede, Dorothea and Brad Inwood (eds.). Language and Learning: Philosophy of Language in the Hellenistic Age: Proceedings of the Ninth Symposium Hellenisticum. Cambridge: Cambridge University Press, 2005.

Giannakis, Giorgos, Vit Bubenik, Emilio Crespo et al. Encyclopedia of Ancient Greek Language and Linguistics. Vols. I-II. Leiden: Brill, 2014.

Ildefonse, Frédérique\& Jean Lallot. Aristote, Catégories. Présentation, traduction et commentaries. Paris: Vrin, 2002.

Irwin, Terence H. "Plato's Heracliteanism". The Philosopical Quarterly 27 (1977), 289-301.

Irwin, Terence H. "Aristotle's Concept of Signification". In Malcolm Schofield and Martha Nussbaum (eds.), Language and Logos: Studies Presented to G. E. L. Owen. Cambridge: Cambridge University Press 1982, 241-266.

Karamanolis, George E. Plato and Aristotle in Agreement? Oxford: Clarendon Press, 2006.

Kotzia, Paraskevi. "Philosophical Vocabulary". In Anastasios-Foivos Christidis, Maria Arapopoulou and Maria Chriti (eds.) A History of Ancient Greek: From the Beginnings to Late Antiquity. Cambridge: Cambridge University Press, 2007, 1089-1103.

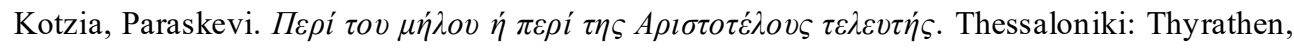
$2007 b$.

Kotzia, Paraskevi and Maria Chriti. "Ancient Philosophers on Language". In Giorgos Giannakis, Vit Bubenik, Emilio Crespo et al. Encyclopedia of Ancient Greek Language and Linguistics. Vols. I-II. Leiden: Brill, 2014, 124-33.

Lee, Henry D. P. Aristotle, Meteorologica. The Loeb Classical Library. London: Heinemann. Cambridge, Massachusetts: Harvard University Press, 1962.

Louis, Pierre. Aristote, Météorologiques I. Vol. I et II. Paris: Les Belles Lettres, 1982.

Manetti, Giovanni."The concept of the sign from ancient to modern semiotics".In Giovanni Menetti (ed.), KnowledgeThrough Signs. Ancient Semiotic Theories and Practices. Semiotic and Cognitive Studies II. Bologna: Brepols, 1996, 11-40.

Membrez, Gregory. "Metaphor by any Other Name. A Cognitive Linguistic Reassessment of Aristotle's Theory of Metaphor". In Egle Mocciaro and William Michael Short (eds.), Toward a Cognitive Classical Linguistics. The Embodied Basis of Constructions in Greek and Latin. Berlin: De Gruyter, 2019, 207-27. 
Modrak, Deborah K. W. Aristotle's Theory of Language and Meaning. Cambridge: CUP, 2001.

Sorabji, Richard. The Philosophy of the Commentators, 200-600 AD: A Sourcebook. Vol.I, Psychology (with Ethics and Religion). Ithaca and New York: Cornell University Press, 2004.

Swiggers, Pierre and Alfons Wouters. Grammatical Theory and Philosophy of Language in Antiquity. Leuven, Paris, Sterling, Virginia: Peeters, 2002.

Weidemann, Hermann."Gründzüge der aristotelischen Sprachtheorie". In Peter Schmitter (Hrsg..), Sprachtheorien der abendlondischen Antike. Tübingen: Narr, 1991, 170-192. 